\title{
Comparison of Coronavirus Stress and Anxiety Levels in Covid-19 Positive and Negative Healthcare Professionals in a Pandemic Hospital, İzmir Example
}

\section{Bir Pandemi Hastanesinde Covid-19 Pozitif ve Negatif Sağlık Çalışanlarında Koronavirüs Stres ve Anksiyete Düzeylerinin Karşılaştırılması, İzmir Örneği}

(iD Muhammed Mustafa UZAN¹, id Hülya PARILDAR¹, id Nisel YILMAZ², ib Dilek SARIKAYA³, id Nurdan TEKGÜL1

${ }_{1}^{1}$ University of Health Sciences Turkey Tepecik Training and Research Hospital, Clinic of Family Medicine, İzmir, Turkey

2University of Health Sciences Turkey Tepecik Training and Research Hospital, Clinic of Medical Microbiology, İzmir, Turkey

3Üsküdar University Neuropsychiatry Hospital, Clinic of Psychiatry, İstanbul, Turkey

\section{ABSTRACT}

Objective: In this study, it is aimed to detect the presence of anxiety in healthcare professionals who are and are not infected with the new type of coronavirus (Covid) and to reveal the underlying causes of this anxiety.

Methods: This analytical and descriptive study was conducted with 188 healthcare professionals working at University of Health Sciences Turkey Tepecik Training and Research Hospital between 1-30 July 2020. Covid anxiety and perceived stress scale were administered to the participants along questionnaire. The statistics of the study were made with the SPSS 18.0 program. The statistically significant if the "p" value was less than 0.05 .

Results: $40.43 \%$ ( $n=76$ ) of the whole group consisted of individuals who were positive for the polymerase chain reaction test $59.57 \%$ $(n=112)$ were health workers who were not diagnosed with Covid-19. Those who worked in Covid-19 wards or outpatient clinics were more likely to be infected with coronavirus and was statistically significant $(\mathrm{p}=0.014)$. No statistical significance was observed in terms of the total score of the Coronavirus Anxiety Scale between those infected with Covid-19 and those not ( $\mathrm{p}=0.349)$.

Conclusion: There are data that all healthcare professionals are concerned and exhausted during the Covid-19 pandemic. The lack of a difference in anxiety levels between those infected with Covid-19 and those not indicates that healthcare professionals still

\section{ÖZ}

Amaç: Bu çalışmamızda; yeni tip koronavirüs (Covid) ile enfekte olan ve olmayan sağlık çalışanlarında anksiyetenin varlığını tespit etmek ve bu anksiyetenin altında yatan sebeplerin varlığın ortaya çıkarmak hedeflenmiştir.

Yöntemler: Kesitsel ve tanımlayıcı nitelikte olan bu çalışma 01-30 Temmuz 2020 tarihleri arasında Sağlık Bilimleri Üniversitesi Tepecik Eğitim ve Araştırma Hastanesi'nde çalışan 188 sağlık çalışanı ile yapılmıştır. Katılımcılara Covid anksiyete skalası ve algılanan stres ölçeği uygulanmıştır. Araştırmanın istatistiği SPSS 18.0 programı ile yapıldı. "p" değerinin 0,05 'ten küçük olması istatistiksel olarak anlamlı kabul edildi.

Bulgular: Çalışma grubunun \%40,43'ünü $(n=76)$ polimeraz zincir reaksiyonu testi pozitif bireyler oluştururken \%59,57’sini ( $\mathrm{n}=112$ ) ise Covid-19 tanısı almamış sağlık çalışanları oluşturmaktaydı. Covid-19 servislerinde veya polikliniklerinde görev alanlarda coronavirüs ile enfekte olma durumu daha fazlaydı ve istatistiksel olarak anlamliydı $(\mathrm{p}=0,014)$. Covid-19 ile enfekte olanlar ile olmayanlar arasında coronavirüs anksiyete skalası toplam skoru açısından istatistiksel bir anlamlılık gözlenmedi ( $\mathrm{p}=0,349)$.

Sonuç: Covid-19 pandemisi sürecinde tüm sağlık çalışanlarının kaygılı, endişeli ve tükenmiş olduklarına dair veriler bulunmaktadır. Covid-19 ile enfekte olanlar ile olmayanlar arasında anksiyete düzeyleri açısından fark olmaması sağlık çalışanlarının pandemi
Address for Correspondence: Muhammed Mustafa UZAN, University of Health Sciences Turkey Tepecik Training and Research Hospital, Clinic of Family Medicine, Izmir, Turkey

E-mail: mustafauzan65@gmail.com ORCID ID: orcid.org/0000-0002-2111-4520

Cite this article as: Uzan MM, Parıldar H, Yılmaz N, Sarıkaya D, Tekgül N. Comparison of Coronavirus Stress and Anxiety Levels in Covid-19 Positive and Negative Healthcare Professionals in a Pandemic Hospital, i̇mir Example. Bezmialem Science 2022;10(5):560-8

${ }^{\circledR}$ Copyright 2022 by the Bezmiâlem Vakıf University

Bezmiâlem Science published by Galenos Publishing House.
Received: 09.08.2021

Accepted: 26.08.2021 
have concerns about the pandemic. A widespread and effective psychosocial support provided by institutions will reduce the negative atmosphere in the health system.

Keywords: Covid-19, healthcare professionals, Coronavirus anxiety scale konusunda hala endişelerinin olduğunu göstermektedir. Kurumların vereceği yaygın ve etkin bir psikososyal destek sağlık sistemindeki olumsuz havayı azaltacaktır.

Anahtar Sözcükler: Covid-19, sağlık çalışanları, Koronavirüs anksiyete skalası

\section{Introduction}

Coronavirus disease-19 (Covid-19) has been defined as a coronavirus disease that has been declared as a pandemic by the World Health Organization (WHO) and develops due to the newly defined severe acute respiratory syndrome coronavirus-2 (SARS-CoV-2) (1). Covid belongs to a large family of viruses and it is known to cause diseases such as common cold, pneumonia and SARS-CoV (2). According to WHO, published on March 3 , 2020, the fatality rate of coronavirus is $2.4 \%$ worldwide (3). Covid-19 is spread through droplets from symptomatic or asymptomatic patients (4). The first patient in our country was detected on March 10, 2020 (5). Measures such as social distancing, hand washing and using masks have been taken to prevent rapid spread (6). In addition to these measures, curfew restrictions started in our country, as in many countries (7). In addition, a 14-day quarantine rule was applied to suspicious patients and people from abroad. By these measures, the spread rate of the virus was reduced and a plateau effect in the casetime curve was achieved (8). On June 1, 2020, a step in the normalization process was taken in our country with a decrease in the number of patients. However, as the number of patients increased again in our country with the end of the summer season, curfew restrictions restarted in the last period of November (9).

Healthcare professionals have spent a lot of effort in this difficult process in which dynamic and continuous rapid decisions have been made. With the establishment of pandemic hospitals, many healthcare professionals in different positions have switched to a new working order (10). Reasons such as intense work pace, variable working hours and constant use of personal protective equipment have caused fatigue and wear out in healthcare professionals over time. The fact that 601 (3.8\%) of the patients diagnosed at the beginning of April were medical personnel increased the concern (11). In the ongoing process, the rights of all healthcare professionals to leave and quit were restricted starting in mid-March (12). This restriction, which was temporarily lifted during the summer period, was re-applied during the second peak period (13). Along with all these, the continuous updating of diagnostic/follow-up/treatment algorithms related to Covid-19 has caused instability and then anxiety and despair in healthcare professionals. Although the success of some pharmaceutical companies in Vaccination Studies against Covid-19 in the last quarter of 2020 has raised hopes, it can be said that the Covid-19 pandemic will not end in the short term $(14,15)$.
The purpose of this study was to determine the level of anxiety in healthcare professionals who were infected and who were not infected with coronavirus, to reveal the presence of emotional stress caused by coronavirus and to identify other triggers underlying this anxiety.

\section{Method}

It is a cross-sectional descriptive study. While 76 healthcare workers with positive Covid-19 polymerase chain reaction tests were used as the study group, 112 healthcare workers who were not diagnosed as having Covid-19 constituted the control group. The necessary approval for the study was obtained from The University of Health Sciences Turkey İzmir Tepecik Training and Research Hospital Clinical Research Ethics Committee (decision no: 2020-7-15/date: 08.06.2020).

Participants and Procedure: Our study was conducted with 188 healthcare professionals active in our hospital between 1-30 July 2020, which coincided with the first (1) peak period of coronavirus in our country. The data were collected on a purely voluntary basis with the consent and permission of the individuals. The questionnaire was prepared on the internet in accordance with the social distance rule. The internet address associated with the questionnaire was delivered via text message to the mobile phones of healthcare professionals. In the questionnaire developed by the researchers, questions were examining sociodemographic characteristics (age, gender, marital status, etc.), the working order of healthcare professionals in the Covid-19 pandemic period and whether they received mental support during this period. The Turkish version of the "Covid anxiety scale" and the short form of the "perceived stress scale (PSS)" were also applied in the questionnaire.

Coronavirus Anxiety Scale: The Coronavirus anxiety scale is a 5 -question scale with robust reliability $(\alpha=.93)$ based on a study with $\mathrm{n}=775$ people (16). In our study, it was determined as $(\alpha=0.95)$. Cronbach is often used in Alpha Likert-type scales. Cronbach is defined as unreliable if Alpha is $0<\mathrm{R} 2<0.40$, low reliable if $0.40<\mathrm{R} 2<0.60$, very reliable if $0.60<\mathrm{R} 2<0.80$ and highly reliable if $0.80<\mathrm{R} 2<1.00$ (17). The Turkish version of the Coronavirus anxiety scale was translated by Evren et al. (18), and its validity and reliability were approved. The necessary permission was obtained from the author at this stage, provided that it was properly cited. Questions on this scale are; "I felt dizzy, dazed or unconscious when I read or listened to the news about the 
coronavirus, I had trouble falling asleep or staying asleep because I thought about the coronavirus, I felt paralyzed or frozen when I thought about the coronavirus or was exposed to information, I lost interest in eating when I thought about the coronavirus or was exposed to information, I felt nauseous or had stomach problems when I thought about the coronavirus or was exposed to information". The answers to these questions and the score equivalent are: "None $=0$, Rare, Less than one or two days=1, More than a few days=2, More than seven days $=3$, Almost every day in the last two weeks $=4$.

Perceived Stress Scale: The PSS was developed by Cohen, Kamarck and Mermelstein (1983) and designed to measure the degree of several situations which were perceived as stressful in an individual's life. In addition to the long-form with 14 items, it has two other forms with 10 and 4 items (19). In this study, a 4-question short form was used. Two questions are with straight statements and 2 questions are with reverse expressions. These questions are: "How often did you feel that you couldn't control the important things in your life last month? How often have you relied on your ability to address your personal problems in the past month? How often did you feel that everything was going well in the last month? In the last month, how often did you feel that problems had accumulated so much that you couldn't overcome them?" The answers to these questions and the score equivalent are: "Very often $=4$, Quite often $=3$, Sometimes $=2$, Almost never $=1$, Never $=O$ ". It is known that PSS scores have a significant and positive relationship with life events and depression, and a negative and significant relationship with life satisfaction, self-esteem and social support (19). A high total score means that the perceived stress level is high (20). Considering that the predicted reliability levels for the scales planned to be used in the studies were 0.60 and 0.80 , the Cronbach's alpha score of the scale for this study was 0.61 and showed internal consistency (20-22).

\section{Measures}

While determining the sample, it was aimed to reach all healthcare workers infected with Covid-19. The study was terminated due to the presence of health workers who did not accept to participate in the study and the end of the first peak period in the pandemic.

\section{Statistical Analysis}

Statistical evaluation was made with SPSS 18.0 program. Validity and reliability analysis of applied Likert-type questionnaires were performed. The compliance of continuous variables to normal distribution was tested. Comparisons of independent groups were made using the "Student's t-test for variables conforming to the normal distribution, and the "Mann-Whitney U" test for those not conforming to the normal distribution. Categorical variables were presented as frequencies and percentages with cross-tables and their distributions were compared with "chi-square" test methods. In all statistical comparison tests, the margin of error of the first type was determined as $\alpha: 0.05$, and the difference between groups was considered statistically significant if the value of "p" was less than 0.05 .

\section{Results}

One hundred eighty eight health workers, including the control group, participated in our study. Of participants $40.43 \%$ ( $n=76)$ tested positive for Covid-19. Of them, 59.57\% ( $\mathrm{n}=112)$ were not diagnosed as having Covid-19, and this group constituted the control group (Table 1).

Of the health workers who tested positive for Covid-19, 76.31\% $(n=58)$ were in the 20-39 age range. Of the control group 54.48\% $(n=61)$ were in the 20-39 age range. Of healthcare professionals who tested positive for Covid-19 36.8\% ( $\mathrm{n}=28)$ were male and $63.2 \%(n=48)$ were female, while $34.8 \%(n=39)$ of the control group were male and $65.2 \%(n=73)$ were female (Table 1$)$.

There was a significant association between Covid-19 negative status and age increase $(\mathrm{p}=0.002)$. While there was no significant relation between Covid-19 negative status and gender and marital status, a significant relationship was found between Covid-19 negative status and high educational level $(\mathrm{p}=0.049)$. It was significant that the physician group was less Covid-19 positive than the nurses/obstetricians and other assistant healthcare personnel $(\mathrm{p}=0.001)$. In addition, there was a statistically significant relation between the increase in years of work and a lower rate of Covid-19 positivity ( $\mathrm{p}=0.008$ ) (Table 1 ).

The percentage of health workers who considered themselves at risk, including the control group, was $84.04 \%(\mathrm{n}=158)$, while the percentage of health workers who said they had anxiety during this process was $88.30 \%(n=166)$. Although there were numerically many anxious health workers, the rate of those who said they needed psychological support during the pandemic period was $38.83 \%(\mathrm{n}=73)$. However, the percentage of those receiving psychological support was $21.80 \%(n=41)$. Of those who received support, only $29.27 \%(\mathrm{n}=12)$ received professional support. The percentage of those who thought their job was always stressful was $44.68 \%(\mathrm{n}=84)$ (Table 2$)$.

The health workers were more likely to be infected with Covid-19 when there was at least one of the family member diagnosed as having Covid-19 ( $\mathrm{p}=0.000)$. The health workers were less likely to be infected with Covid-19 if they were assigned in another unit by leaving the current unit of work $(\mathrm{p}=0.000)$ (Table 3$)$.

There was a significant relationship between the status of getting infected with Covid-19 and serving only on the day shift (08:00-17:00) ( $\mathrm{p}=0.015)$. The higher levels of Covid-19 negative status were significant in those who served in pandemic services or outpatient clinics than those who did not $(\mathrm{p}=0.014)$. It was statistically significant that those whose working time did not change during the pandemic had a higher level of Covid-19 positivity than those whose working time did $(\mathrm{p}=0.003)$ (Table 3).

The average Coronavirus anxiety scale score of all participants was 3.03, while the average value of the total score of the PSS short form, another important scale, was 8.04 (Table 4).

No statistical significance was observed in terms of the total score of the Coronavirus anxiety Scale between those who tested 
Table 1. Comparison of sociodemographic data with control group

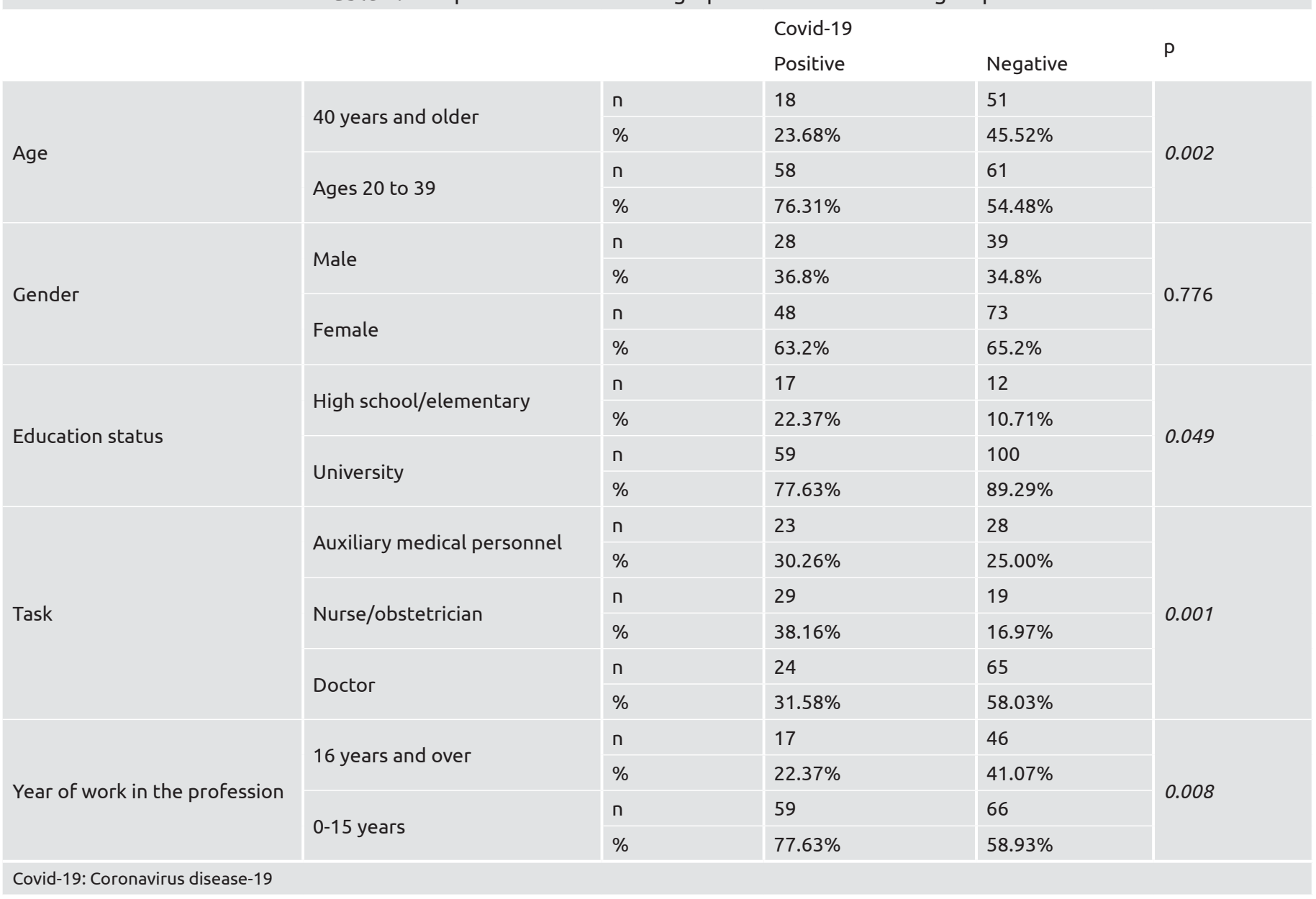

positive for Covid-19 and the control group ( $\mathrm{p}=0.349)$. Similarly, no statistical significance was observed in terms of the total score of the PSS (short form) between those with positive Covid-19 test and the control group $(\mathrm{p}=0.290)$ (Table 4).

Compared to the educational level of all participants and the total score of the Covid anxiety scale; it was statistically significant that the anxiety level decreased as the educational level increased $(\mathrm{p}=0.006)$. When the total score of Covid anxiety scale was compared with working in pandemic outpatient clinics or services, it was found that the anxiety level did not increase statistically $(\mathrm{p}=0.504)$. The Covid anxiety scale score of those receiving mental support was high, and it was statistically significant that those with high anxiety levels also needed mental support $(\mathrm{p}=0.001)$ (Table 5).

Considering the answers given in the Covid anxiety scale, the sample size and the statistical significance value, when we accepted the cut off value as " 1 ", no statistically significant difference was observed in terms of the scale value between Covid-19 positive group and the control group ( $\mathrm{p}=0.556)$. Also, no statistically significant difference was observed in terms of the scale value between participants who worked for 16 years or over and who worked for $0-15$ years, and between those who worked in outpatient clinic or service and who did not $(\mathrm{p}=381$ and $\mathrm{p}=474$, respectively) (Table 6).

\section{Discussion}

Healthcare professionals, who have to work 24 hours a day without interruption under the stress of being primarily responsible for health, experience psychological and physiological disorders due to the increased workload (23). These can occur in the form of health problems such as chronic insomnia, fatigue, fear of causing malpractice, burnout syndrome, concentration disorders, chronic diseases, and some types of cancer (24). Furthermore, trying to fight an pandemic that they did not know about before has affected medical personnel too much $(25,26)$. In our study, no relation was found between coronavirus infection status and both the Covid anxiety scale and the PSS scores. It can be said that those who fully carry out infection protocols/procedures have both avoided being infected with coronavirus and that their stress level has not changed. Although the presence of a continuous infection creates a persistent level of anxiety, it can be said that being infected with Covid-19 does not cause much variability on the anxiety.

In our study, it was observed that anxiety levels decreased as education levels increased, and stress increased in the presence of infected or suspected patient contact with Covid-19. Some studies showing that anxiety and insomnia are more common in doctors and nurses who come into contact with possible or diagnosed patients $(27,28)$. We can say that those with a high 
Table 2. Anxiety status of all participants ( $n=188)$

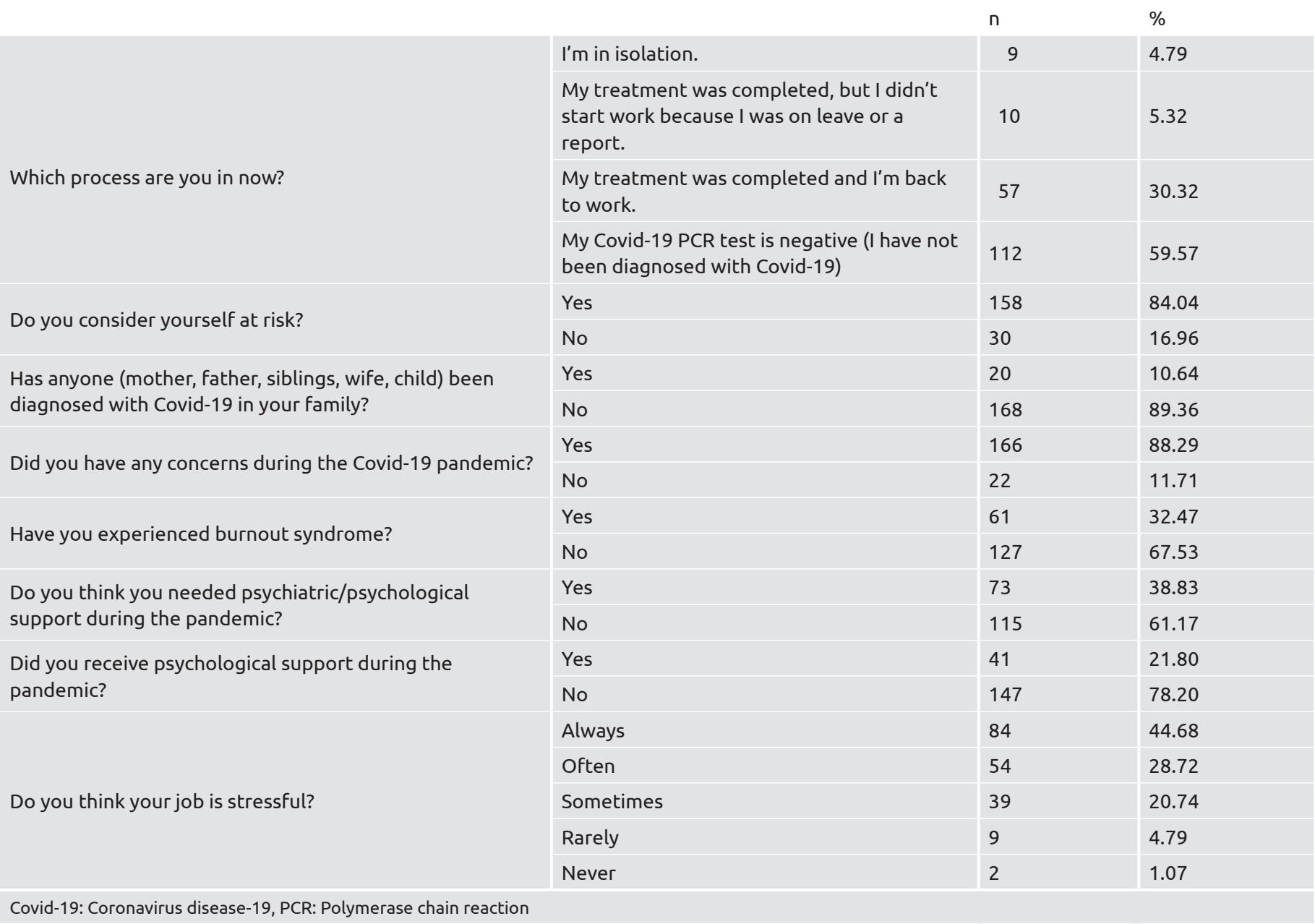

level of education can access sufficient data in the light of evidence-based medicine, and accordingly, the level of anxiety decreases. On the other hand, we believe that when it comes to contact with a suspicious patient, it creates an exacerbation of the anxiety level again.

Chan and Huak (29). found that doctors were 1.6 times more likely to experience psychiatric symptoms than nurses. Another study showed high levels of sleep problems, anxiety, and depression symptoms in healthcare professionals (30). In addition, Ataç et al. (31) stated in the study that while anxiety symptoms in nurses/obstetricians and dentists were higher than other professions, doctors constituted the occupational group with the least anxiety symptoms. In our study, it was found that the physician group was less likely to be infected with coronavirus than the nurse/obstetrician and other auxiliary medical personnel. As the years of working in the profession increased, the rate of Covid-19 positivity decreased. It can be concluded that a doctor with high experience in the profession has a low level of being infected with Covid-19, while other healthcare professionals have a higher level of being infected with Covid-19 and a higher level of anxiety than doctors.

In a study on the anxiety levels of individuals, Tutku et al. (2) found that women's health anxiety perception levels were high. Moreover, another study found that levels of anxiety and depression in women were significantly associated with the Covid-19 pandemic (32). Our study is similar to this aspect. We believe that being a woman, as well as being a medical staff, deepens the level of anxiety in this process.

Looking at the researches on Covid-19, some studies are showing that lower levels of psychological impact, depression and anxiety are detected with more preventive measures (33). Ataç et al. (31) found that there was no significant difference in anxiety and insomnia both according to the current task unit and according to the new tasks carried out during the pandemic period. Polat and Coşkun (34) found that healthcare professionals who used their personal protective equipment appropriately when necessary had low depression, anxiety and stress scores. Likewise, in a study conducted in China, it was reported that individuals with high mask-wearing rate who took part in this process had lower DASS depression and anxiety subscales scores (35). In our study, similarly, working in Covid-19 outpatient clinics or services did not increase the level of anxiety. Those who did not work in Covid-19 outpatient clinics or services had a higher rate of Covid-19 than those who worked. Based on this, strict measures taken at the first point of close contact can be considered to have reduced the level of anxiety. On the 
Table 3. Comparison of Covid-19 pandemic working order with control group

\begin{tabular}{|c|c|c|c|c|c|}
\hline & & & Covid-19 & & D \\
\hline & & & Positive & Negative & P \\
\hline & Yes & $n$ & 17 & 3 & \\
\hline Has anyone (mother, father, siblings, & res & $\%$ & $22.37 \%$ & $2.68 \%$ & \\
\hline Covid-19 in your family? & $\mathrm{No}$ & $n$ & 59 & 109 & 0.000 \\
\hline & IV & $\%$ & $77.63 \%$ & $97.32 \%$ & \\
\hline & Yes & $n$ & 20 & 61 & \\
\hline $\begin{array}{l}\text { Has the service or space you worked } \\
\text { in during the Covid-19 pandemic been }\end{array}$ & res & $\%$ & $26.32 \%$ & $54.46 \%$ & 0.000 \\
\hline changed? & No & $n$ & 56 & 51 & 0.000 \\
\hline & NO & $\%$ & $73.68 \%$ & $45.54 \%$ & \\
\hline & & $n$ & 12 & 21 & \\
\hline & Just a sinite & $\%$ & $15.79 \%$ & $18.75 \%$ & \\
\hline & Only full-time working every & $n$ & 21 & 11 & \\
\hline How was your working order during the & day (8.00-17.00) & $\%$ & $27.63 \%$ & $9.82 \%$ & \\
\hline Covid-19 pandemic? & & $n$ & 13 & 28 & 0.075 \\
\hline & Unly rlexidle working nours & $\%$ & $17.11 \%$ & $25.00 \%$ & \\
\hline & Both shift and overtime & n & 30 & 52 & \\
\hline & together if necessary & $\%$ & $39.47 \%$ & $46.43 \%$ & \\
\hline & Yes & $n$ & 33 & 69 & \\
\hline Did you serve in the Covid-19 outpatient & res & $\%$ & $43.42 \%$ & $61.61 \%$ & 0014 \\
\hline clinic or service? & & $n$ & 43 & 43 & 0.014 \\
\hline & No & $\%$ & $56.58 \%$ & $38.39 \%$ & \\
\hline & My working time has & n & 12 & 28 & \\
\hline & increased & $\%$ & $15.8 \%$ & $25.0 \%$ & \\
\hline Any changes in your working time & My working time hasn't & $n$ & 35 & 25 & 0.003 \\
\hline pandemic? & changed & $\%$ & $46.1 \%$ & $22.3 \%$ & J \\
\hline & My working time has been & $n$ & 29 & 59 & \\
\hline & reduced & $\%$ & $38.2 \%$ & $52.7 \%$ & \\
\hline
\end{tabular}

Table 4. Comparison of coronavirus survey scale and perceived stress scale of Covid-19 negative and positive individuals $(n=188)$

\begin{tabular}{|c|c|c|c|c|c|}
\hline \multicolumn{2}{|c|}{ Coronavirus anxiety scale } & n & Mean SD med. & Min-max & $p$ \\
\hline \multirow[b]{2}{*}{ Covid-19 state } & Positive & 76 & $2.70 \pm 3.91(1.00)$ & $(0.00-17.00)$ & \multirow[b]{2}{*}{0.349} \\
\hline & Negative & 112 & $3.25 \pm 4.56(1.00)$ & $(0.00-20.00)$ & \\
\hline \multicolumn{2}{|c|}{ Perceived stress scale } & n & Mean SD med. & Min-max & $p$ \\
\hline Covid-19 state & Positive & 76 & $7.75 \pm 2.91(8.00)$ & $(0.00-14.00)$ & 0.290 \\
\hline
\end{tabular}

other hand, it can be interpreted that those who do not work in Covid-19 departments are more easily infected by assuming that they are away from the danger zone.

Anxiety disorders are known to become more pronounced with a decrease in interpersonal communication and with the cessation of social support (36). It should be noted that all kinds of psychological events disrupt the general functioning of the body with prolonged stress, laying the ground for not only Covid-19 but many infections or exacerbating psychosomatic diseases (26). In a multicenter study in Turkey; the perception of stigma score in those who received psychological support during the Covid-19 pandemic and who had psychological disorders during or before the Covid-19 pandemic outbreak were found 
Table 5. Comparison of data with Coronavirus anxiety scale ( $n=188)$

\begin{tabular}{|c|c|c|c|c|c|}
\hline & & $n$ & Mean SD med. & Min-max & $p$ \\
\hline \multirow{2}{*}{$\begin{array}{l}\text { Year of work in the } \\
\text { profession }\end{array}$} & 16 years and over & 63 & $3.32 \pm 4.70(1,00)$ & $(0.00-20.00)$ & \multirow{2}{*}{0.946} \\
\hline & $0-15$ years & 125 & $2.88 \pm 4.11(1,00)$ & $(0.00-20.00)$ & \\
\hline Age & Ages 20 to 39 & 119 & $2.87 \pm 4.17(1.00)$ & $(0.00-20.00)$ & 0.721 \\
\hline Education level & University & 159 & $2.71 \pm 4.06(1.00)$ & $(0.00-20.00)$ & 0.006 \\
\hline \multirow{2}{*}{$\begin{array}{l}\text { Did you receive } \\
\text { psychological support during } \\
\text { the pandemic? }\end{array}$} & Yes & 41 & $5.17 \pm 5.51(4.00)$ & $(0.00-20.00)$ & \multirow[b]{2}{*}{0.001} \\
\hline & No & 147 & $2.43 \pm 3.72(1.00)$ & $(0.00-20.00)$ & \\
\hline \multirow{2}{*}{$\begin{array}{l}\text { Has the service or space } \\
\text { you worked in during the } \\
\text { Covid-19 pandemic been } \\
\text { changed? }\end{array}$} & Yes & 81 & $2.91 \pm 3.84(1.00)$ & $(0.00-17.00)$ & \multirow[b]{2}{*}{0.902} \\
\hline & No & 107 & $3.11 \pm 4.65(1.00)$ & $(0.00-20.00)$ & \\
\hline $\begin{array}{l}\text { Did you serve at the } \\
\text { Covid- } 19 \text { outpatient clinic or } \\
\text { service? }\end{array}$ & No & 86 & $2.55 \pm 3.32(1.00)$ & $(0.00-16.00)$ & 0.504 \\
\hline \multirow{2}{*}{$\begin{array}{l}\text { Did you have contact with a } \\
\text { patient who was diagnosed } \\
\text { with Covid- } 19 \text { while working? }\end{array}$} & Yes & 113 & $3.00 \pm 3.79(2.00)$ & $(0.00-17.00)$ & \multirow{2}{*}{0.012} \\
\hline & No & 34 & $1.50 \pm 3.03(0.00)$ & $(0.00-16.00)$ & \\
\hline
\end{tabular}

Table 6. Comparison of data by cut-off value "1" on the coronavirus anxiety scale

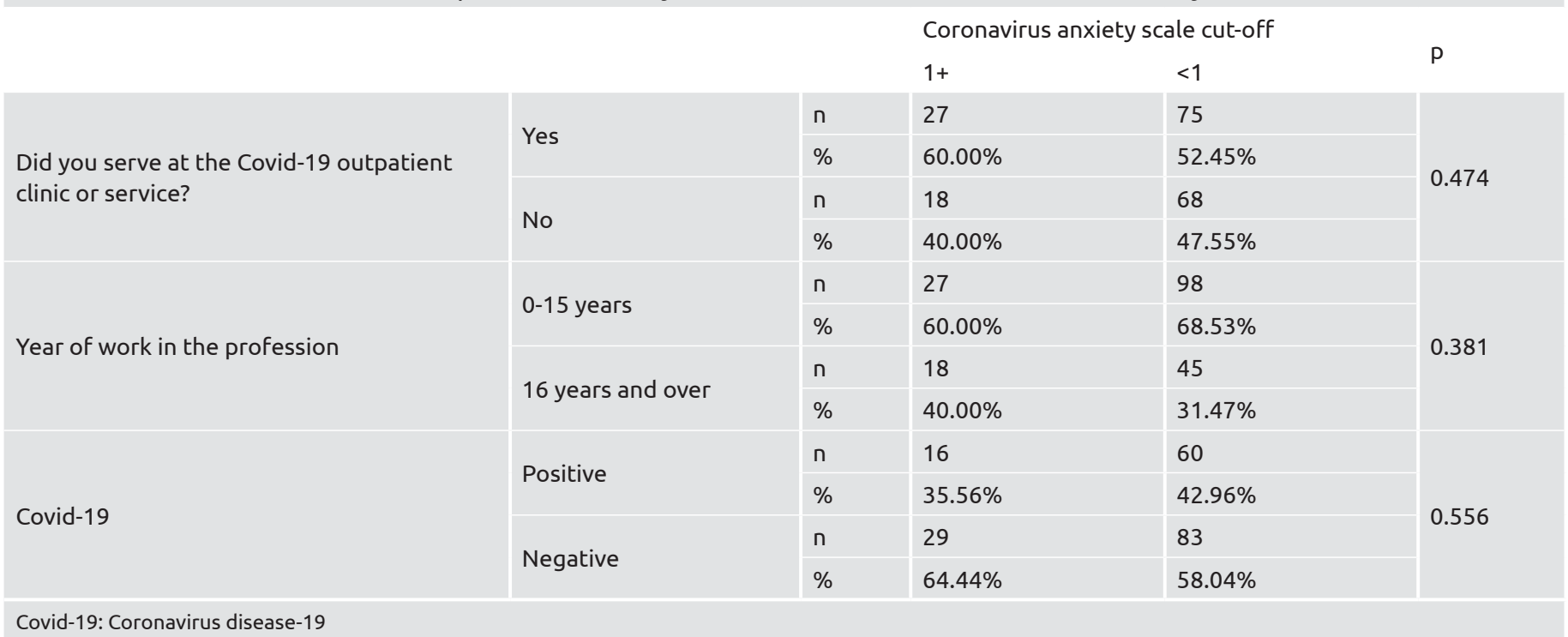

to be significantly higher (37). In our study, those who said they needed mental support had a higher score in the Covid anxiety scale, while those who had high anxiety levels also needed mental support. We believe that the morale and motivation of health workers should be increased throughout the pandemic and that institutions should provide all kinds of support in terms of psychological support.

No cut-off value was detected for the Covid anxiety scale in studies $(16,18)$. In the score table, when the cut off value "9" was taken as a basis, $90 \%$ sensitivity and $85 \%$ specificity were found, and $71 \%$ sensitivity and $74 \%$ specificity were found when " 5 " was taken as a basis $(16,18)$. In our study, we considered the cut-off as "1". Accordingly, no significant difference was found between those with " 1 and above" and those with a " $O$ " in terms of the frequency of Covid-19. It can be concluded that there is no change in the individual's current level of anxiety, whether the person is infected with coronavirus or not.

\section{Study Limitations}

The limitations of our study were that the Covid anxiety scale used in our study did not have a certain cut-off value and the sample size did not include primary health care institutions. 


\section{Conclusion}

Those fighting on the front lines against the pandemic are healthcare professionals. A staff with a high level of anxiety does not have any change in the anxiety level after being infected, indicating that the individual is now hopeless and bored. The fact that the healthcare professionals' anxiety level does not decrease indicates that their concerns about Covid-19 persist. The service of a disenchanted healthcare professional will reduce the quality of health, as well as lead to dangerous consequences such as medical malpractice, burnout or suicide.

At this point, we believe that institutions should be as committed to protective equipment as they are to social or psychological support. A widespread, effective and sustainable psychosocial support will lead to efficient service in the health system.

Acknowledgements: Thanks to all the healthcare professionals who participated in our study.

\section{Ethics}

Ethics Committee Approval: University of Health Sciences Turkey İzmir Tepecik Training and Research Hospital Clinical Research Ethics Committee (decision no: 2020-7-15/date: 08.06.2020).

Informed Consent: Informed consent was obtained from the patients for this study.

Peer-review: Externally peer reviewed.

\section{Authorship Contributions}

Concept: M.M.U., N.Y., D.S., Design: M.M.U., H.P., N.T., Data Collection or Processing: M.M.U., N.Y., Analysis or Interpretation: M.M.U., H.P., N.Y., D.S., N.T., Literature Search: M.M.U., H.P., N.T., Writing: M.M.U., H.P., D.S., N.T.

Conflict of Interest: No conflict of interest was declared by the authors.

Financial Disclosure: The authors declared that this study received no financial support.

\section{References}

1. Sohrabi C, Alsafi Z, O’Neill N, Khan M, Kerwan A, Al-Jabir A, et al. World Health Organization declares global emergency: A review of the 2019 novel coronavirus (COVID-19). Int J Surg 2020;76:71-6.

2. Tutku E, Ilıman E, Dönmez E. Comparison Of Health Anxiety Level And Control Perception Of Covid-19. Usaysad Derg 2020;6:139-54.

3. WHO Director-General's opening remarks at the media briefing on COVID-19. https://www.who.int/director-general/speeches/detail/ who-director-general-s-opening-remarks-at-the-media-briefing-oncovid-19---3-march-2020 E.T:07/12/2020

4. Rothe C, Schunk M, Sothmann P, Bretzel G, Froeschl G, Wallrauch C, et al. Transmission of 2019-nCoV Infection from an Asymptomatic Contact in Germany. N Engl J Med 2020;382:970-1.

5. https://www.saglik.gov.tr/TR,64383/koronavirus-alacagimiztedbirlerden-guclu-degildir.html E.T.: 20/10/2020
6. World Health Organization, Novel Coronavirus (2019-nCoV) Advice for the Public, (2020) https://www.who.int/emergencies/ diseases/novel-coronavirus-2019/advice-for-public E.T:07/12/2020

7. https://www.icisleri.gov.tr/duyuru1004 E.T. 20/10/2020.

8. https://www.saglik.gov.tr/TR,65192/yogun-bakim-yatak-dolulukoranimizi-yuzde-60lara-indirdik.html E.T. 20/10/2020

9. https://www.icisleri.gov.tr/koronavirus-salgini-yeni-tedbirler E.T.21/11/2020.

10. https://covid19.saglik.gov.tr/TR,66495/pandemi-hastanesi.html E.T. $20 / 10 / 2020$

11. https://www.bbc.com/turkce/live/haberler-dunya-52088533 E.T.06/12/2020

12. https://shgm.saglik.gov.tr/TR,64726/covid-19-salgini-suresincesaglik-kuruluslarinda-saglik-personel-ayrilislari.htmlE.T:16/12/2020

13. https://www.bbc.com/turkce/live/haberler-turkiye-54701006 E.T:16/12/2020

14. https://www.bbc.com/turkce/haberler-dunya-54919704 E.T:07/12/2020

15. https://www.bbc.com/turkce/haberler-dunya-54962498 E.T:07/12/2020

16. Lee SA. Coronavirus Anxiety Scale: A brief mental health screener for COVID-19 related anxiety. Death Stud 2020;44:393-401.

17. Uzunsakal E, Yıldız D. A Comparison Of Reliability Tests In Field Researches And An Application On Agricultural Data. Uygulamalı Sosyal Bilimler Dergisi 2018;2:14-28.

18. Evren C, Evren B, Dalbudak E, Topcu M, Kutlu N. Measuring anxiety related to COVID-19: A Turkish validation study of the Coronavirus Anxiety Scale. Death Stud 2020;46:1052-8.

19. Eskin M, Harlak H, Demirkıran F, Dereboy Ç. The Adaptation of the Perceived Stress Scale Into Turkish: A Reliability and Validity Analysis. New Symposium Journal 2013;51:132-40.

20. Bilge A, Öğce F, Genç RE, Oran NT. Algılanan Stres Ölçeği (Asö)'Nin Türkçe Versiyonunun Psikometrik Uygunluğu. Ege Üniversitesi Hemşirelik Yüksek Okulu Dergisi 2009;25:61-72.

21. Tavşancıl E. Tutumların Ölçülmesi ve SPSS ile Veri Analizi. 2. Baskı, Ankara; Nobel Akademik Yayıncılık; 2005.

22. Özdamar K. Paket Programlar ile İstatistiksel Veri Analizi. 4. Baskı. Eskişehir: Kaan Kitabevi; 2002.

23. Kıroğlu F. Covid-19 Pandemi Ortamında Çalışma Koşulları ve Genel Sorunlar. Meyad Akademi 2020;1:79-90.

24. Meydanlığlu A. Health and Safety of Health Care Workers. Balıkesır Health Sciences Journal 2013;2:192-9.

25. Greenberg N, Docherty M, Gnanapragasam S, Wessely S. Managing mental health challenges faced by healthcare workers during covid-19 pandemic. BMJ 2020;368:1211.

26. Baltacı NN, Coşar B. COVID-19 pandemisi ve ruh beden ilişkisi. İçinde: Coşar B, editör. Psikiyatri ve Covid-19. 1. Baskı. Türkiye Klinikleri; Ankara: Türkiye; 2020.p.1-6.

27. Uzun ND, Tekin M, Sertel E, Tuncar A. Psychological and social effects of COVID-19 pandemic on obstetrics and gynecology employees. J Surg Med 2020;4:355-8. 
28. Zhang WR, Wang K, Yin L, Zhao WF, Xue Q, Peng M, et al. Mental Health and Psychosocial Problems of Medical Health Workers during the COVID-19 Epidemic in China. Psychother Psychosom 2020;89:242-50.

29. Chan AO, Huak CY. Psychological impact of the 2003 severe acute respiratory syndrome outbreak on health care workers in a medium size regional general hospital in Singapore. Occup Med (Lond) 2004;54:190-6.

30. Lai J, Ma S, Wang Y, Cai Z, Hu J, Wei N, et al. Factors associated with mental health outcomes among health care workers exposed to coronavirus disease 2019. JAMA Netw Open 2020;3:e203976.

31. Ataç Ö, Sezerol MA, Taşçı Y, Hayran O. Anxiety and insomnia among healthcare workers during the COVID-19 pandemic. Turk J Public Health 2020;18(Suppl):47-57.

32. Wang C, Pan R, Wan X, Tan Y, Xu L, Ho CS, et al. Immediate psychological responses and associated factors during the initial stage of the 2019 Coronavirus disease (COVID-19) epidemic among the general population in China. Int J Environ Res Public Health 2020;17:1729.
33. Leung GM, Lam TH, Ho LM, Ho SY, Chan BH, Wong IO, et al. The impact of community psychological responses on outbreak control for severe acute respiratory syndrome in Hong Kong. J Epidemiol Community Health 2003;57:857-63.

34. Polat Ö, Coşkun F. Determining the Relationship Between Personal Protective Equipment Uses of Medical Healthcare Workers and Depression, Anxiety and Stress Levels in the COVID-19 Pandemic. Med J West Black Sea 2020;4:51-8.

35. Li Z, Ge J, Yang M, Feng J, Qiao M, Jiang R, et al. Vicarious traumatization in the general public, members, and non-members of medical teams aiding in Covid-19 control. Brain Behav Immun 2020;88:916-9.

36. Xiao C. A novel approach of consultation on 2019 novel coronavirus (COVID-19)-related psychological and mental problems: structured letter therapy. Psychiatry Investig 2020;17:175-6.

37. Teksin G, Uluyol OB, Onur OS, Teksin MG, Ozdemir HM. Stigmarelated factors and their effects on Health-care Workers during COVID-19 Pandemics in Turkey: A Multicenter Study. Med Bull Sisli Etfal Hosp 2020;54:281-90. 